Vol. 16, $n^{\circ} 2$ | 2012

Varia

\title{
"To be remedied of any vendetta" : Petitions and the Avoidance of Violence in early modern Parma
}

Colin Rose

\section{OpenEdition}

\section{Journals}

Electronic version

URL: http://journals.openedition.org/chs/1355

DOI: $10.4000 /$ chs.1355

ISSN: 1663-4837

Publisher

Librairie Droz

Printed version

Date of publication: 1 December 2012

Number of pages: 5-27

ISBN: 978-2-600-01642-1

ISSN: $1422-0857$

\section{Electronic reference}

Colin Rose, «"To be remedied of any vendetta" : Petitions and the Avoidance of Violence in early modern Parma », Crime, Histoire \& Sociétés / Crime, History \& Societies [Online], Vol. 16, n² | 2012

Online since 01 December 2015, connection on 01 May 2019. URL : http://journals.openedition.org/ chs/1355; DOI : 10.4000/chs.1355 


\title{
"To be remedied of any vendetta" : Petitions and the Avoidance of Violence in early modern Parma ${ }^{1}$
}

\author{
Colin Rose ${ }^{2}$
}

\begin{abstract}
Les Ducs de Farnèse dominèrent la province de Parme, en Italie du Nord, de 1548 à 1731. Un aspect important de leur domination fut leur ouverture aux requêtes et supplications de leurs sujets. Ces pétitions destinées à des souverains absolus, émanant de sujets de diverses positions sociales, fournissent une documentation très riche sur les relations entre ducs ou princes et les populations sur lesquelles ils régnaient. La thèse de cet article est que les sujets du duché de Parme utilisaient les canaux de communications offerts par le système bien établi des pétitions et des requêtes en appel pour s'épargner l'obligation de résoudre querelles et conflits sociaux par la violence. Il est important de noter que les malfaiteurs paraissent eux-mêmes avoir calculé leurs crimes en fonction de la probabilité d'un pardon ducal, en cherchant à menacer plutôt qu'à blesser, ou à insulter plutôt qu'à agresser. Le système des requêtes était géré par le Consiglio della Dettatura, tribunal faisant partie intégrante du système judiciaire farnésien. Lors du déclin de cette dynastie, ce système permettait à une grande partie des sujets des Farnèse de protéger leurs intérêts tout en se soumettant à l'autorité ducale.
\end{abstract}

The Farnese dukes dominated the province of Parma, north Italy, from the period 1548 to 1731. An important characteristic of their rule was their receptiveness to petitions and supplications from their subjects. Petitions from subjects of varying social positions to absolutist rulers provide a wealth of information pertaining to the relationships between dukes or princes and the populations they ruled. This article argues that the subjects of the Farnese duchy of Parma relied on the relationships of channels of communication provided by a well-entrenched system of petitions and appeals as a way to relieve themselves of the obligation to resolve quarrels and social conflicts

$1 \quad$ The author is grateful to the anonymous readers for their careful criticism and suggestions. This article is indebted to the support of many colleagues: Dr. Gregory Hanlon, who supervised the research; Dr. Nicholas Terpstra, who supervised the writing; Dr. Edward Muir and the graduate students of Northwestern University; the many colleagues from the University of Toronto who contributed time and ideas, particularly John Christopoulos and Vanessa McCarthy; and to Saman Jafarian. The author gratefully acknowledges the financial support of the Social Sciences and Humanities Research Council of Canada.

2 Colin Rose is a PhD Candidate in History at the University of Toronto, Canada, where he also completed his Bachelor of Arts before taking his Master's degree at Dalhousie University, Halifax, Canada. His research interests relate to the intersections of social and legal history, specifically longterm criminal and deviant behaviour seen through a social lens. His dissertation in progress will survey homicide rates in Bologna, Italy, from the period of 1550-1700 to test the hypothesis of a European decline of violence against a Northern Italian archival sample. He currently works in the archives of the Tribunale del Torrone, Bologna's secular criminal court in the early modern period. 
through violence. Importantly, malefactors also seem to have calculated their crimes in accordance with the likelihood of receiving a ducal pardon, tending to threaten rather than wound, or insult rather than attack. The system of petitioning was operated by the Council of Sentencing (Consiglio della Dettatura), a tribunal that developed as an integral part of the Farnese judiciary system. By the waning of the Farnese dynasty, petitioning allowed a broad swath of Farnese subjects to protect their own interests while submitting to the authority of the ducal regime.

\section{INTRODUCTION}

Tate in October, 1637, one Alessandro Mariano wrote a petition to the duke of Parma, Odoardo Farnese (1622-1646). Mariano complained that, earlier in August, he was investigated by the Parman chief criminal judge, the Auditore Criminale, because "he might have killed Gironimo di Pastori in the village of Borghetto [...] and because [Mariano] wishes to prove his innocence in this crime of which [he] was impugned, he has decided to turn himself in." However, Mariano's petition went on to explain, "he doubts that some evil will not be ordered against him when he will be in prison." Therefore, his petition requested that "[Mariano] may not be interrogated for any other matter than for the abovementioned homicide"s. What these other matters were, the petition did not say. However, Mariano's chief concern was the possibility of being punished for the murder which he apparently did not commit, and Mariano opted to surrender to the authorities rather than risk a sentence in absentia. The duke ratified the petition, and added that Mariano would be granted a safe conduct on condition that he spent ten days in jail in Parma upon his surrender.

This article is about petitioning and violence, and their intersection in seventeenthcentury Parma. Why did Mariano surrender to the authorities for a violent crime he did not commit, and why was he incarcerated regardless? What purpose did his petition serve in this case? Here, petitioning refers to the process by which subjects appealed to authorities for assistance in resolving a wide range of issues; in Italy, this constituted a system of supplications written by notaries, working within judicial structures. Historians have done much work on petitions in the last decade, noting the ability of petitions to increase the personal power of a ruler, often at the expense of bureaucratic processes or even in prejudice to the rights of higher authorities ${ }^{4}$. Petitioning in France also served to strengthen the institutions of royalty and government, if the royal body's presence produced a lasting effect of obedience through the passage of a royal tour ${ }^{5}$. Muchembled used French petitions explicitly to study violence in Artois, and argued that while adhering to a standard of truth and being revealing of people's habits and customs, they do not provide historians with

Archivio di Stato di Parma (hereafter ASPR), Supremo Consiglio di Giustizia e di Grazia e Consiglio della Dettatura, Suppliche e Memoriali, bb.43, \#1166.

4 An early, and very astute, analysis of the ways in which petitions (in this case, for homicide pardon) served the interests of both the royal authority and the petitioners themselves is Davis (1987). Cf. Logette (1994); Niccoli (1995, 2007); Nubola (2001); Nubola, Wurgler (2004); Nubola, Belloni (2006); Repetti (2000).

5 Gauvard (1997, p. 281). 
direct access to a history of criminality ${ }^{6}$. Early modern Europeans used petitions to place their behaviour into ordinary, or even banal, circumstances, and thus petitions reveal much about the role of violence in social life in the early modern world.

At the same time, recent scholarship into the ducal states of early modern Italy has revealed the ways in which aspiring rulers meddled in the affairs of their magistracies, subverted their own orders, or ignored official corruption in order to pursue a more expansive supreme authority situated in the ducal persona ${ }^{7}$. Subjects and supplicants themselves were also inclined to strategic use of court systems. From the medieval period, a time associated with the rationalization of courts, citizens and residents of cities used litigation to damage their enemies, by staining their reputations or instigating an endless series of judicial processes against them ${ }^{8}$. Early modern courts were thus arenas of negotiation, between individuals, and between individuals and institutions, in which the subjects of absolutist governments both propagated and resolved their social conflicts 9 .

Europeans' use of courts to settle conflicts expanded at the same time as historical rates of violence declined in a long-term process ${ }^{10}$. Violence in this article is primarily empirical: it refers to physical aggression between individuals or groups with the aim of inflicting wounds or humiliation. This could be either reciprocal or one-sided victimization. Manuel Eisner's 2003 database of historical data on violent crime throws its empirical decline into sharp relief, revealing that from England to Finland, in the Netherlands as in Switzerland and Germany, rates of interpersonal violence fell dramatically, with Italy experiencing a decline later, in the midnineteenth century ${ }^{11}$. Eisner's synthesis demonstrates the strength of a comparative, quantitative method in this field: in order to assess properly the behavioural changes that Europeans seemingly underwent, a longue durée analysis of statistical trends, with consideration of source quality and the roles played by specific social groups in any findings, is necessary to document the incidence of violence itself. This was done for the British Isles in the 1970s, but has not been done for specific regions of Italy and much of the continent ${ }^{12}$.

However, a statistical picture of levels of violence can simply demonstrate the phenomenon, not explain it. Here, agreement among historians falters, and explanations derive from two streams of thought. The first stream follows Elias' theory of the civilizing process. Scholars in this vein argue that changes to sociocultural forces, notably concepts of male honour, reduced the violent tendencies of European males. The argument, simplified for brevity, goes as follows. As Europeans

\footnotetext{
$6 \quad$ Muchembled (1989, p. 17)

7 Chambers, Dean (1997, pp. 113-146 \& 179-232); Terpstra (2001); Waquet (1992, p. 153).

8 Smail (2003, pp. 89-132).

9 Mantecón (2006).

10 These rates of violence are usually expressed in homicide rates, as a measure of violent deaths per 100,000 people. Two survey works cover most of the literature concerning non-fatal violence as well as homicide. Eisner (2003) provides the background to any case study of non-fatal violence ; Spierenburg (2008) emphasizes the decline of fatal violence and the transformation of notions of "honour" among elites as the mitigating factor most germane to the long-term decline.

11 Eisner (2003, pp. 95-99). Eisner>s data for Italy are not as complete as for other areas ; more archival work needs to be done in both North and South Italian archives before firm conclusions may be reached.

12 Beattie (1974); Cockburn (1991); Given (1977); Hammer (1978).
} 
defined male honour less by lineage and physical strength, and more so by personal comportment, fashion and good manners, deadly elite violence gave way to stylized duels; the lower classes responded by developing their own honour codes and ritualizing their own violence ${ }^{13}$. Historians have modified the civilizing process to pertain to violence, and have confirmed its applicability to observable declines in violence $^{14}$. The increasing criminalization of violence by state authorities, according to these authors, did more than just cause people to consider the costs of their actions : Spierenburg argues that demonstrable changes in levels of human aggression and its typologies are the manifestations of genuine changes to human emotional make-up, as a result of which humans are not only less inclined to violence, but less capable of the inclination itself ${ }^{15}$.

A counter-school of thought sees violence as a social strategy available to all people at all times, who employ it among other tools, such as the law, to advance what they see as their interests and thus give it some kind of communicative meaning. Anton Blok takes this view in his anthropological work, noting that "people have developed strong feelings about [...] violence. They are inclined to consider[...] [it] as the antithesis of civilization," before arguing for violence's strong communicative power ${ }^{16}$. For historians, this has meant a reconsideration of the decline of violence and its place in early modern society. Thus, Stuart Carroll argues against the civilizing process and the expansion of the French monarchy as determining factors in the decline of elite violence in sixteenth-century France. French nobility retained the prerogative to use violence strategically to advance their own interests; if they chose not to do so, it was because they recognized better opportunities for social and personal advancement in their local social milieus and within the royal house's expansion, while in fact the duel did not constitute a ritualized violence, but an amplified and more bloody violence indeed ${ }^{17}$. Gregory Hanlon and Paul Hyams take views similar to Carroll's in their works on conflict in seventeenth-century Italy and late-medieval England. Hanlon brings forth the many arenas of minor and deadly conflict between Tuscan villagers and illuminates the fact that "there was a variety of individual responses to different problems"18. Hyams looks at attempts by medieval English kings to extend a "king's peace" and dampen the incidence of feud, and finds that even if monarchy wished to centralize, and to impose a standard of behaviour on nobles, feuding remained a basic category of social interaction for medieval English elites $^{19}$. Common among these cases is the idea that cycles of retributive violence tend to be self-limiting, because the costs of endless violence are not practically bearable ${ }^{20}$.

This article seeks to unify these two views by proposing that while early modern Europeans continued to consider, and to exercise, violence as a functional strategy of social competition, this functionalism was curbed by the evolution of institutional

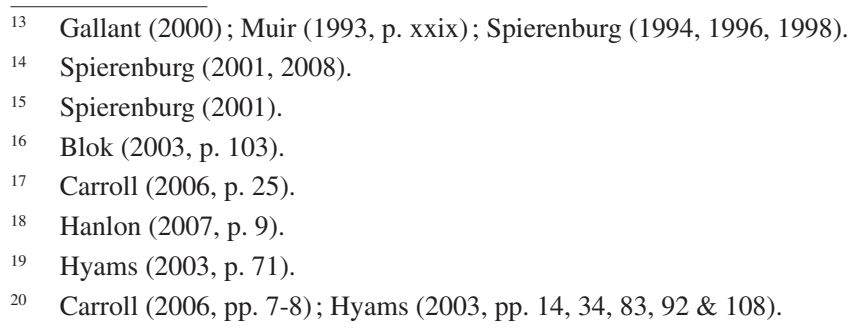


structures encouraging conflict resolution through negotiation and participation in legal systems ${ }^{21}$. People retained the propensity for violence in many situations, as they do today. However, processes of centralization and absolute expansion had real effects on the choices made by ordinary people. When presented with options that offered non-violent solutions to conflicts, subjects tended to pursue these routes, and over time these options became first the best and then the only functional options within the bounds of society. We should therefore look for practical explanations of how European peoples managed the control of violence throughout the early modern period. Historians need to consider how populations seized the opportunity for active participation in the control of community violence. This study assesses how the process of petitioning the ducal court constituted one such mechanism in seventeenth-century Parma, Italy.

The duchy of Parma in the seventeenth century is an appropriate focus for such a study for two reasons. First, the seventeenth century may be considered a period of governmental stability in Italy. The absolute states that formed in the sixteenth century had, for the most part, established themselves under firm dynastic control by the early seventeenth century ${ }^{22}$. The Farnese overcame local opposition to their rule in 1612, and reigned in an unbroken line until 1731. They are a paradigmatic absolute dynasty. Thus, the duchy of Parma provides a stable background against which we may isolate violence and petitioning to determine their interaction. Second, seventeenth-century Italy has not received the attention paid to the fifteenth and sixteenth centuries in English scholarship, particularly with regards to the interactions between absolute states and their populations. One goal is thus to encourage scholars to look beyond traditional "renaissance" periodization to find continuities and disruptions between these centuries.

\section{THE SCENE OF THE CRIME : THE JUDICIARY OF PARMA IN THE SEVENTEENTH CENTURY}

The duchy of Parma was located in north-central Italy, south of the Po and west of Bologna. In the seventeenth century, its population was approximately 300,000 between the cities of Parma and Piacenza, and the outlying towns and settlements. The dukes referred to here, Odoardo I (1622-1646) and Ranuccio II (1646-1694) were ducal monarchs who received petitions from their subjects through a body known as the Council of Sentencing (Consiglio della Dettatura $)^{23}$. These petitions

21 For the study of violence in particular, historians must not avoid confronting the psychological and behavioural influences that lay behind the expression of culture, including violence. Cf. Blaffer-Hardy, Hausfater (1984); Daly, Wilson (1988); Diamond (1992, pp. 223-316) ; Pinker (2002, pp. 306336). Historians working with these materials include Hanlon (2007) and Hyams (2003). A recent issue of the British Journal of Criminology (Eisner, 2011) is devoted to the application of evolutionary models to violence across a range of topics, from violence in non-state societies to judicial violence in Nazi Germany. Steven Pinker's monograph on the grand historical decline of violence phrases this interaction of individual and institutional pacification in terms of human mental and emotive inclinations towards or away from violence (2011).

22 I here use «absolute» as a signifier, while recognizing that the reality of early modern monarchical states was much more fluid and dependent upon negotiation and elite goodwill. Cf. Henshall, (1992); Collins (2009). A recent analysis of the importance of petitions for an emergent absolute dynasty is Shaw (2012).

23 The roles of the maternal regents who governed during the minority of these two dukes begs investigation. 
constituted an important element of the judicial system. Parmans could write petitions addressing civil and criminal issues. They divide loosely into six categories: Judicial (asking for pardon for a crime), Protection (requesting help solving private conflicts), Favour (seeking employment at the court, for instance), Charity (often from widows or young women), Tax Reduction or Extension, and Debt Relief or Collection. Petitions thus drew a range of issues under the authority of the Farnese judiciary. The Farnese dukes entrusted the administration of the Dettatura to a series of officers and Presidents, whose powers and responsibilities expanded over time as the Farnese saw opportunities to increase the reach and efficiency of government.

The Dettatura was the appeals court of a judicial system that combined central courts with a network of councils and officials that brought information and people into Parma from the countryside. In the city, a chief criminal judge (Uditore Criminale) relied upon a rudimentary system of police (sbirri) to apprehend criminals, and he had independent responsibility for urban cases as well as for those from the many fiefs in Farnese land. He judged from three criminal benches in Parma. This judge also decided cases involving feudal, military and poaching laws. His membership on the Supreme Council of Justice and Mercy, which vetted all sentences of death, mutilation or long-term galley service, gave him jurisdiction over the entire Farnese territory. At the same time, the judge needed the approval of this Supreme Council to approve his sentences of execution, mutilation, or long-term galley service. Investigations in the countryside were carried out by municipal governors (Podestà) who reported their conclusions to the Supreme Council in Parma ${ }^{24}$. The Dettatura functioned as an appeal court in this system. Plaintiffs and defendants could request pardon from the Dettatura, while the criminal judge and his counterpart, the civil judge, could each request a decision, taken by vote, from the council's members ${ }^{25}$. The Dettatura's decisions were confirmed by the President of the Supreme Council, who was also a member of the Council of Sentencing. The membership of the Dettatura included the presidents of the Fiscal Camera, which governed tax and budgetary matters, and the Congregation of the Communes, which governed the widespread operations of rural village councils ${ }^{26}$. Thus, the Dettatura brought a range of competencies under one jurisdiction, and this efficient centralization of the appeals process is characteristic of the relatively simple judiciary of the Farnese state.

Two key elements of the Farnese judiciary provide the "official" view of the petitioning process. These are the magistracy responsible for the system's operation (Consiglio della Dettatura), and a book of prescriptions (the Rituale) that regulated the fees and other administrative business arising from petitioning. The Consiglio della Dettatura was one of the most powerful bodies in the administration of the Parman state throughout the seventeenth century and until the end of the Farnese dynasty in $1731^{27}$. It possessed ultimate jurisdiction over most criminal and civil

The involvement of the duchess Dorotea in eighteenth-century petitions may hint that they too received, adjudicated and declared on the petitions of regular subjects. Without a body of petitions addressed to either of them, likely conserved in the Archivio di Stato di Parma, a thorough analysis of their priorities and those of their petitioners is precluded, but this is certainly an area of research worth pursuing.

24 Di Noto (1980, pp. 91-105).

25 Di Noto (1980, p. 75).

26 Ibid.

27 The council was originally established by Ranuccio I in 1594. At that time, it possessed jurisdiction over both the major cities of the Farnese State. Confusion and inefficiencies, as well as accusations 
matters, arbitrating disputes and determining penalties for crimes. The dukes of Parma found in this council a means of entry into the daily affairs of subjects. Its role as such helped to effect a shift that would see the population turn first to the courts and the state for assistance in solving conflicts, before violence overcame them ${ }^{28}$.

However, the dukes imposed limits on the ability of the Dettatura to act on its own authority. The council had the right to decide whether to grant or to reject a petition, but it had to draft the response (rescritto) according to certain rules laid out in the Rituale, a book compiled with the duke's approval ${ }^{29}$. This book regulated the taxes on criminal petitions (suppliche), ascribing certain fees for a pardon for crimes depending on their severity and the likelihood of the petition being granted. Thus, although given a certain amount of responsibility, the Dettatura was nevertheless always under the thumb of the dukes.

The rules of that ducal thumb were found in the Rituale noted above, which exhaustively lists the gamut of appealable issues - specifically pardonable crimes and the fines that attended a petition. The Rituale lists the prescribed fees for supplications in a section entitled 'Regula Generales Dictaturce'. The preamble continues with some basic guidelines for supplication. For instance, no homicide committed in anger could be supplicated without a three-year interval and the prior concession of a pax from the victim's family, thus encouraging the killer to make his primary amends with the victims $\mathrm{s}^{30}$. This requirement has medieval antecedents based on the notion that homicide was primarily an offense against a victim's kin, and secondarily against the king's law. In medieval England, the king's attempts to act against homicide were thwarted by the determination of the nobility to demand their own satisfaction and peace-making processes ${ }^{31}$. By the early modern period, however, Italian governments freely prosecuted homicides using inquisitorial process, so no complaint from family was required to initiate an investigation. The requirement for a peace accord in Parma is thus a functional continuity reflecting structural change. While prosecuting homicides as crimes, the Farnese also allowed the victims' families a modicum of input. This not only legitimized the duke's pardon, by ensuring its acceptance among the victims of crime, but also ensured that potential retributive violence was foresworn by those likely to take vengeance. The manual also dictates a general rule for the taxation of supplications, that the

of localism and favouritism, soon led the duke to withdraw the Dettatura to Parma while instituting a separate Ducal Council in Piacenza. It originally oversaw the arbitration of civil disputes submitted by subjects, but when its efficiency and usefulness were made clear to Ranuccio, he expanded its jurisdiction to include civil and criminal cases, as well as those emanating from the feudal territories of Busseto and the upper Taro valley. The five-man council thus received petitions from Farnese subjects until 1731. These petitions, or a great deal of them, are conserved in the Archivio di Stato di Parma, in the collection of Consiglio della Dettatura, Suppliche e Memoriali.

28 Other programs were aimed at noble pacification as described by Angelozzi (2003); Di Simplicio (1994).

29 Biblioteca Palatina di Parma (hereafter BP), MS Parmeggiane, Miscellanea Farnesiana, \#554. This document was written anonymously in 1596, shortly after the council was instituted by Ranuccio I. It systematically defines the duties of much of the Farnese judiciary while also tabulating the penalties affixed to the punishment of delicts, and establishes the terms of pardon in Parma.

30 BP, MS Parmeggiane, Miscellanea Farnesiana, \#554, p. 3. The granting of a peace accord from the victim's kin to the slayer was a common requirement of pardons for homicide across the continent. Hurnard (1969); Davis (1987); Smail (2003).

31 Hyams (2003). 
fee for a granted petition be set at $1 / 5$ the potential judicial fine for the pardoned crime $^{32}$. Finally, before listing the prescribed fees, the guide describes how to craft a rescritto, the different types of which are examined in Paola Repetti's analysis of the crafting of Parman suppliche ${ }^{33}$. The Rituale amounted to a formalization of the means of petitioning: if they wished to access ducal mercy, Parmans were required to follow a defined series of legal actions, beginning with the drafting of a petition, that emphasized the unequal power relationships between ruler and ruled. Moreover, the Council's development over time allowed the Farnese to continue drawing private dispute settlement into the legal framework of the state. This association of private and public justice afforded the dukes a concrete identification with the social problems and needs of their subjects, while at the same time pacifying the behavioural responses of Parmans to threatening situations.

Regardless of their input into the system, Farnese dukes did not review or involve themselves in the majority of their subjects' petitions. They were content for most petitions to be treated on a day-to-day basis by their high magistrates. However, they promulgated decrees (gride) that modified the terms and function of the Dettatura, and these decrees are indicative of the attitudes with which they viewed petitioning and its relationship to their authority. The success and failure rates of ordinary petitions, and those petitions that bore ducal scrutiny, show how petitions encouraged subjects to work within the Farnese judiciary. This system allowed Parmans to express their social needs while at the same time constraining their behaviour, or the behaviour of their social adversaries.

Like the Tudor monarchs of England, Farnese dukes publicised special decrees of general pardon, called decreti gratiosi, which celebrated a momentous occasion in the dynastic household such as a royal birth or the ascendancy of a new duke ${ }^{34}$. In 1628, Odoardo declared one such decree to celebrate his marriage to Margherita de'Medici, the daughter of Cosimo II $^{35}$. Margherita's signature on the decree was her formal entry into the role of Duchess (Duchessa), and the general pardon that accompanied the ducal marriage was an attempt to affiliate the subject population, and its welfare, with the Farnese dynasty and its future as represented by the young duke and his new bride. A new general pardon was decreed in 1629 to celebrate the Duchess' pregnancy with Odoardo's son Ranuccio, the future Ranuccio II; this decree was extended and renewed repeatedly ${ }^{36}$. The last renewal came in February 1631 and noted specifically the duke's awareness that his previous decrees had not served "those who are far away, or truly for diverse reasons have been prevented from being able to enjoy the benefits of the said decree" 37 . To remedy this, the decree commanded senior officials in Parma, Piacenza, Borgo san Donnino and the Congregation of the Communes (Congregazione sopra Comuni) to publicize the month-long extension as widely as possible to ensure that all subjects had effective access to the general pardon. Public demonstrations of the strength of the Farnese

BP, MS Parmeggiane, Miscellanea Farnesiana, \#554, p. 2.

Ibid., I-IV; Repetti (2000, pp. 301-305).

On the general pardon in England, see Kesselring (2003, pp. 56-90).

ASPR, Gride, \#184.

ASPR, Gride, \#202; Ibid., \#229, unnumbered decrees of 2 and 5 March 1629.

ASPR, Gride, \#229. 
dynasty were accompanied by royal grace to cement their subjects' identification of well-being with the stability of the Farnese.

The dukes also used irregular decrees to transform judicial offices. In a 1661 decree addressed to both the officers and notaries of the Dettatura, Duke Ranuccio II laid out the grounds on which his councillors would best fulfil his "personal patronage no less than [their] public service" 38 . This decree was a comprehensive rendering of the necessary security of the Dettatura's physical offices and of the document archive it governed. The offices had two keys, kept by the chancellor and vice-chancellor. Only the chancellor or vice-chancellor were authorised to write and sign rescritti in the name of the duke, and if supplicants requested copies, they were required to do so of the Dettatura's staff notaries and the copy itself had to be made within the Dettatura's offices. The decree ordered that originals of all supplications be kept under lock and key. Responsibility for the maintenance of security and the inviolability of the Dettatura's physical edifice, and hence their political and moral authority, was given to the two chancellors already tasked with responding to supplicants. In this way, the duke drew a direct line of authority from himself, through the chancellor and vice-chancellor, to those subjects who abased themselves at the feet of his magistrates and begged his assistance in their social conflicts.

The decline in violence, the growth of ducal authority in the princely states of the Italian peninsula, and the formalisation and regulation of the means for subjects to appeal to and petition the state authorities are intimately related. As Italian states crystallised in the seventeenth century, systems of petitioning became more expansive, encompassing a broader range of issues from criminal pardon to social assistance and tax relief ${ }^{39}$. Like their counterparts in other major and minor cities, the Farnese consistently prescribed harsh penalties and mediated their application in practice. Additionally, after a brief spike in numbers in 1636, capital punishment in Parma declined to a level averaging about one a year by 1700 , and one every three years thereafter ${ }^{40}$. No longer inclined to demonstrate their power through the public gallows, the Farnese exploited the potential of suppliche. The Farnese income from petitions constituted approximately one percent of annual revenue in the late seventeenth century, and cannot be considered a significant windfall. The Farnese dukes instead recognised that petitioning could help to stabilise a population that was increasingly dependent upon the ability of a single dynastic house to maintain order in the cities and villages of the state. As a reliable means to solve problems without the risks of violence, petitioning drew Farnese subjects away from private justice and into the expanding judiciary.

\section{PETITIONS, VIOLENCE AND PERSONAL RULE}

1,440 petitions drawn from six bundles at approximate fifteen-year intervals from Parma demonstrate how Farnese subjects approached the apparatus of government and attempted to influence the decisions of high-level officials ${ }^{41}$. Additionally, a

ASPR, Gride, V40:94, unnumbered decree of 29 June 1661.

39 Forclaz (2006, pp. 76-77 \& 166-181); Cancila (2009, p. 323).

40 Meredith (2008, pp. 92-103).

41 The records of the Consiglio della Dettatura are conserved in the font Supremo Consiglio di Giustizia e di Grazia e Consiglio della Dettatura, Suppliche e Memoriali in the Archivio di Stato di Parma. 
series of administrative materials and correspondence reveal the 'official' workings of the Council, and how the Farnese dukes involved themselves personally in the appeals by subjects and influenced the decisions of senior magistrates. Those cases in which the dukes, particularly Ranuccio II, took a personal interest illuminate clearly the configuration of princely politics that is also visible in the workings of the Medici regime. The combination of judicial correspondence and petitions allows for a qualitative assessment of the ways in which petitioning constituted a reciprocal process.

Table 1: Number of petitions per category per year in Parma. ${ }^{42}$

\begin{tabular}{|c|c|c|c|c|c|c|c|}
\hline Year & CR & P & F & C & TR & DR & Total \\
\hline 1631 & 78 & 2 & 0 & 0 & 76 & 0 & 156 \\
\hline 1637 & 198 & 3 & 4 & 1 & 197 & 0 & 403 \\
\hline 1644 & 12 & 13 & 57 & 0 & 2 & 13 & 97 \\
\hline 1659 & 3 & 8 & 25 & 4 & 4 & 16 & 60 \\
\hline $1687-9$ & 96 & 1 & 0 & 0 & 355 & 4 & 456 \\
\hline 1727 & 7 & 21 & 136 & 102 & 0 & 10 & 276 \\
\hline Total & 394 & 48 & 222 & 107 & 634 & 43 & 1448 \\
\hline
\end{tabular}

As Table 1 demonstrates, the petitions from the early seventeenth century refer primarily to criminal matters, with a scattering of civil misdemeanours and financial issues throughout the bundles. This is partly due to the impact of the Thirty Years War, as well as the lasting trauma of recurrent plague cycles. Thus, in both 1631 and 1637, petitions requesting judicial pardon accounted for close to 50 percent of petitions (78/156 and 198/403 respectively), indicating that subjects, particularly the soldiers who were numerous in the city in this decade, tended to shoot or rob first, and ask for pardon later. Petitions from later in the century were more varied in subject matter, and those which concerned violent criminality are much reduced by 1687-1689, when they accounted for less than 25 percent (96/456) of the serie's total. Thus, a decline in the proportion of petitions presented to the duke requesting reprieve from the penalties of crime and violence may indicate two things. The first is that interpersonal violence in Parma declined over the period. This article cannot prove this decline statistically; however, it is in line with much of the evidence for a European decline in violence. The second is that violent resolution of interpersonal

There are approximately 250 bundles of petitions dating from the mid-sixteenth until the nineteenth century (the Supremo Consiglio remained in operation until 1815, first under Spanish rule and then under and after Napoleon). My selection of bundles was essentially random. My goals were to establish a representative chronology of Farnese subjects over the seventeenth century, and to view these subjects within different contexts, such as plague recovery. The one non-random selection was the bundle from 1637, which was chosen specifically because it followed a humiliating 1636 military campaign launched by Odoardo Farnese. The chance to read a high volume of soldiers' and militiamen's petitions pushed me to select this year specifically.

$42 \mathrm{CR}=$ criminal reprieve $\mathrm{P}=$ protection $; \mathrm{F}=$ Favour $\mathrm{C}=$ Charity $; \mathrm{TR}=$ Tax Relief $; \mathrm{DR}=$ Debt Relief. The selections of bundles was essentially random, with the exception of 1637, chosen for its proximity to the Battle of Tornavento in 1636. Source: ASPR, Supremo Consiglio di Giustizia e di Grazia e Consiglio della Dettatura, Suppliche e memoriali, Bb 40, 43, 45, 5, 60, 65. 
conflicts gave way to appeal to judicial forces, and the growing number of petitions requesting ducal protection from enemies supports this notion. These types of petitions accounted for 1.2 percent of petitions in $1631(2 / 156)$, more than 10 percent in $1659(8 / 60)$ and 7 percent in $1727(21 / 276)$.

However, this program of intensely personalised power relied fundamentally on the active participation of both the dukes and their subjects in the system of petitioning. Parman citizens knew the system, and used it well. The Farnese judiciary operated under the inquisitorial system, and subjects progressed through it as follows: The complaint of a plaintiff was not required to initiate procedure. Upon the report of a crime, either by denunciation or because it was discovered some other way, a police force (sbirri) attempted to apprehend the criminal. If they were successful, the suspect faced inquisitorial trial behind closed doors by the Uditore Criminale or one of his assistant judges, and was subjected to torture in order to ensure full and truthful disclosure ${ }^{43}$. Once interrogation was complete, the judge compiled reports of questions and answers, and provided this evidence to the defence, who then had the opportunity to review it with the accused. The defence then compiled his own report and gave it to the judge, who pronounced sentence. This concluded the initial phase of the judicial process. The Dettatura could become involved in two ways. First, the judge himself could request input from the Dettatura into his decision, and the council would vote on the issue and return their answer ${ }^{44}$. This was done in cases where the outcome was unclear, in cases of disputes where the parties were of sufficiently high status to challenge the decision by a single judge, or where the judge felt that the additional input of the Dettatura would give the sentence more gravity, especially in capital cases where ordinary judges did not have the competency to declare a death sentence unilaterally. Alternatively, if the defendant was declared guilty and sentenced, he or she could appeal the sentence directly to the council, by having a notary draft a petition to the council that outlined the reasons why the defendant believed him- or herself worthy of pardon. If convinced, the judges of the council drafted the rescritto according to the established rules.

The familiarity of subjects with the necessary formulae for successful petitions indicates that appealing to the Dettatura was a regular aspect of the early modern Parmans' daily encounter with state authority. The broad range of issues they petitioned and the prominence of particular social groups, such as militiamen, show that Parmans strategised their petitions and may have refrained from submitting a supplica until they considered their chances of success to be most favourable. Further, certain petitions provide very suggestive evidence for an active turn by Parman subjects to state authority in avoidance of personal conflict and violence. The ways in which the Farnese dukes, particularly Ranuccio II, treated these exceptional petitions illustrate the conception of princely rule that motivated their interference with the judicial system, and link the pacified behaviour of Parman subjects to the strengthening of the personal ruler through visible and functional communicative mechanisms.

A sample will make clear the material analysis of petitions below. The following is the petition of Antonia Mussona, who in 1644 was brought in front of the Criminal Judges (Auditori Criminali) for her involvement in a quarrel with unknown enemies. She addressed herself to the Dettatura as below:

\footnotetext{
43 On the inquisitorial system of continental Europe generally, see Spierenburg (1984, pp. 8-9).

44 Di Noto (1980, p. 71).
} 
Antonia Mussona, humble servant and petitioner of your Supreme Illustrious Magistrates, reminds you how she has been molested by the Criminal Office of Parma that wants to punish her for a fight, and make one of her sons pay her fine. But the petitioner being poor, having nothing else from which to live, because her husband consumed all she had and not having any more, it was necessary to go into service to support herself, this way being deprived of two daughters, they having gone to the service of the Serene Prince in Candia. Now the poor petitioner genuflects at the feet of your Supreme Illustrious Magistrates, humbly supplicating that they would consider giving her grace by ordering that the petitioner should no longer be molested for this quarrel, and also that whatever there is about her in the criminal books be overturned, for all this the petitioner hopes to obtain from your Supreme Illustrious Magistrates. Quam Deus ${ }^{45}$.

The communicative strategies employed by Parmans in their petitions are a good starting point to illustrate the active engagement of Farnese subjects in the program of suppliche e rescritti. Petitions all begin with obsequious praise for the benignity of the duke or his officers. This honorific address, clearly stipulated by notarial prudence, took a variety of forms that stressed those ducal qualities that petitioners wished to invoke. Thus, some petitions stress the "most serene" nature of the duke, while others emphasise his royal highness, and others still focus on his "immense clemency and goodness" (immensa clemenza e benignità). The notary likely chose the most fitting obsequy for the petitioner's tale, and then copied the story into the petition. This technique served to establish the abject position of the petitioner, kneeling in tears at the duke's feet for mercy.

The familiarity of subjects with these requirements indicates an almost scripted regularity to Parman petitions, whose literary form is remarkably consistent across the bundles examined here ${ }^{46}$. Parmans identified themselves as "humble and devoted servants" of the duke while at the same time submitting repeated supplications designed to steadily decrease their taxes owed to the crown ${ }^{47}$. Indeed, petitioners understood well the benefit of repeated supplication, and strategised their petitions to address first the legal issue they faced, and secondarily, to evade the fees on petitions themselves. Criminal petitions, particularly, took a typical form. The petitioner, who committed crime $x$, petitioned the Dettatura for the free grace and remission of

45 «L'Antonia Mussona humil.ma serva et oratrice delle ss.ie VVMme gli espone qualmente viene molestat dal officio criminale di Parma col volerla pignorare per una querella, qual pretendono che paghi un suo figliolo, e essendo l'oratrice povera, non havendo cosa alcuna con che vivere, havendosi il marito consumato quanto haveva et non havendo con che vivere, è stata necesitata andare a servire per sostentarsi, come anco essendo priva di due figlioli, essendo andati al servicio del Ser.mo Pincipe in Candia. Hora la povera oratrice genuflesa a piedi delle Ssrie VVMme quelle humil.te supplicando degnarsi fargli gracia di ordinare, che l'oratrice non sia gravata ne molestata per tal causa, et anche sia cassato detta que ne Da come anco altre se ve ne fosse dalle libri Criminali, che tanto l'oratrice spera ottenere dalli Ssrie VVMme Quam Deus. » ASP, Supremo Consiglio di Giustizia e di Grazia e Consiglio della Dettatura, Suppliche e Memoriali, bb. 45.

46 This is much in line with Davis' analysis of petitions, in which particular features of a pardon letter were seen as stock elements indicating the required states of mind, regret and a lack of premeditation, but contrary to Muchembled's study of pardon letters from Artois. Muchembled instead emphasises the mundane aspects of pardon letters, which, he argues, place the misdeeds of French nobility against a background of everyday ordinariness in order to deemphasise their behavioural transgressions. Davis (1987); Muchembled (1992).

47 Margarita Spadania, for instance, submitted two petitions in 1631, progressively lowering the fine she owed for what appears to be a public decency infraction. ASPR, Supremo Consiglio di Giustizia e di Grazia e Consiglio della Dettatura, Suppliche e Memoriali, bb.40, \#905 \& \#1132. 
guilt (ogni gratia e libero dono). These petitions seem overly ambitious, for the magistrates were unlikely to grant such a request for even minor delicts. Common procedure was thus to grant a pardon with certain conditions attached. Gioseffo di Costa, called Fallopieno, received one such pardon in 1637 for insolence to a public official $^{48}$. Attendant to his pardon was a fine of six gold scudi, which di Costa had no intention of paying. He promptly submitted a second petition that emphasised his poverty and previous service in the ducal militia to justify his request to have the fine eliminated, or reduced significantly. Petitioners such as di Costa were prepared to invest a considerable amount of time and effort into pursuing their needs through the Dettatura, even recognising long-term strategies that would reduce the burden of the legal system on their finances and social capital.

The subjects of the Farnese were familiar with the option of presenting a case to a supreme governmental body, and recognised the benefits they could gain by taking this option. Two series of petitions will demonstrate how this relates to the decline of violence. The first concerns petitions that focus on violent crime, or crime-related violence, committed by the petitioner: simple assaults, robberies, brawls and fights that involve weapons. Significantly, this series shows that over the century Parmans, particularly soldiers, developed a preference for firearms display, rather than ritualistic knife fighting as seen elsewhere in Europe. The second series contains petitions that precluded acts of violence, and requested protection from the petitioner's rivals or enemies. Parmans now employed the legal system to their advantage. As noted by the Rituale, the fine for a fight in which blood was spilled, for instance by a skilful knife-fighter's attack on his opponent's cheek, was significantly higher than unlicensed possession or display of a firearm. Thus, in their daily conflicts, Parmans may have considered the costs and benefits of potential violence, specifically their ability to avoid significant punishment by appealing to the Dettatura, and chosen more symbolic means of displaying and acting out status competitions and other disputes in the early modern city.

In 1636, Duke Odoardo led a Parman army to counter the threat of a Spanish invasion of Piacenza ${ }^{49}$. The high numbers of soldiers and militiamen present in the Duchy around the time of Duke Odoardo's experiment with military glory overloaded the records in 1637 with petitions from quarrelsome soldiers. Their petitions show how these men interacted with each other and with the local citizenry. Due to their training, soldiers typically were more inured to interpersonal violence than shopkeepers; these petitions, therefore, are not representative of the violent behaviour of all Parman subjects, but nevertheless display the careful attitude taken towards illicit violence by soldiers ${ }^{50}$. Of course, these men went too far on occasion. There are fifteen extant petitions for homicide in this entire series of petitions, fourteen of which date from the years 1631 and 1637, and all these cases involved soldiers either as aggressors or victims, and frequently both. In these instances, the

48 ASPR, Supremo Consiglio di Giustizia e di Grazia e Consiglio della Dettatura, Supplica e Memoriali bb 43, supplica of Giosetto di Costa, \#849.

49 Parrott (2001, p. 118). While the siege was broken by the aid of a French army which initiated battle with the Spanish at Tornavento on 22 June 1636, Odoardo was left in an untenable political position after the French failed to consolidate their victory and solidify control of the area around Milan. Odoardo made peace with the Spanish in early 1637.

50 On the psychology of soldiers and the training required to inculcate the capacity for violence, see the work on drill and repetition in Grossman (1995). 
Dettatura refused to reintegrate violent offenders into the legal strictures of the state; soldiers who did not resort to fatal violence could expect a much more favourable treatment by the judges.

Soldiers seem actively to have avoided homicidal violence, in order to decrease the difficulty of any potential encounter with the judicial apparatus. That said, they calculated displays of status and strength that minimized the danger of a judicial burden. The least risky display strategy was the public flaunting of a weapon in areas associated with authority, sanctity or safety ${ }^{51}$. Churches fit the bill. On 12 September 1637, Giovanni Domenico Scacalea petitioned the Dettatura to review his sentence for carrying his schioppo, a type of early shotgun, to church in his native village of Torchiana, and to eliminate the fine entirely, based on the record of his militia service to Odoardo $^{52}$. In what must have been a shock to the petitioner given the relatively minor offence, his fine of four gold scudi was confirmed by the Dettatura, who rejected his petition outright. In contrast, Cesare Stachi's petition appealing the outstanding funds of the twelve scudi, that he was fined for twice bringing his gun to church and once pointing it at an adversary during a quarrel, was granted on the basis that he had already paid a fair portion of the balance ${ }^{53}$. The difference accorded to these two petitions indicates that the duke was not wont to give free absolution to misbehaving soldiers; rather, the bonds of fealty and submission created by the payment of even a small amount of money allowed for the advancement of mutual interests. The petitioner avoided more serious punishment and was still able to threaten and intimidate, while the duke drew power to himself by deciding the fate of even minor miscreants.

Churches were not the only public places where soldiers committed this type of firearms infraction. Local festival celebrations were another excellent field on which to demonstrate virility in a public setting without the need to engage in actual violence against an adversary in order to prove dominance. Thus, Diminio Pintio, a musketeer in the ducal militia, was condemned to the regular four gold scudi fine for bringing his loaded weapon to a dance. His petition was rejected because he also pointed the weapon at an official of the local church ${ }^{54}$. The ducal court was also a firearms-free zone. The soldier Giovanni Antonio Gonzi brought his loaded weapon to the court in December 1637 and was assessed a low fine of one scudo, which was repealed subsequently by libero dono ${ }^{55}$. All of these were public areas in which soldiers could take advantage of the judicial structure provided by the regime to display their status in competition with social rivals. They were also places with strict regulations prohibiting public violence. The willingness of soldiers to replace physical violence with aggressive posturing in the public space defined by authority indicates the effectiveness of systems of petitioning in communicating the goals and

51 Hanlon (1985, pp. 244-268). Hanlon notes similar behaviours among Aquitainians, who were more likely to brandish a firearm than to fire it when considering the costs of their action.

52 ASPR, Supremo Consiglio di Giustizia e di Grazia e Consiglio della Dettatura, Suppliche e Memoriali, bb43, \#860.

53 Ibid., \#1017.

54 ASPR, Supremo Consiglio di Giustizia e di Grazia e Consiglio della Dettatura, Suppliche e Memoriali, bb40, \#1039.

55 Ibid., bb43, \#626. 
ambitions of both subjects and the regime, helping to drive any behavioural changes that seventeenth-century Parmans may have undergone.

Gun infractions were not limited to soldiers. On 12 July 1631, Giacinto Bigolli submitted a petition to have the payment on his judicial fine of four gold scudi delayed and broken into instalments ${ }^{56}$. Giacinto was guilty of the public display of his schioppo at the church in Colorno. His petition received the brief rescritto characteristic of petitions arising from minor infractions of no terrible concern to the duke or his magistrates: a brief affirmation of the grace given. However, most firearms infractions were committed by soldiers.

Farnese soldiers and subjects also developed a much more vivid form of postural violence as they moved away from the physical resolution of social conflict to more restrained social relations. As mentioned above, the judicial fines for both the crime and the pardon were increased significantly when a culprit drew blood from his adversary or his victim. Parmans thus adapted a form of non-lethal display violence that required no physical mark like a scar on a cheek to demonstrate the victor's superior status. Numerous petitioners related how, when threatened by adversaries, or desiring to threaten adversaries in turn, they produced their weapon, either from a carrying "holster" or from its storage in their house, and began to load it in front of the man or woman they wished to intimidate and dominate. Thus, Nicolo Orti, a town official from Lizzano di Belvedere, belatedly reported in 1631 that Pietro Rufaldi and two others from Campia di Langhirano "loaded an archebus in front of Lorenzo del Casino, of the said town of Campia"57. Orti's petition in fact asked for forgiveness for neglecting to denounce this infraction.

This case has two particularly tantalizing aspects which throw the motivations of both criminals and authorities into clear relief. First loading a gun was an infraction warranting a denunciation by a public official in an outlying town to a central authority. The importance of interaction between centre and periphery towns in contexts of strong government is clear, as historians have noted in colonial contexts but equally germane to the discussion here ${ }^{58}$. Previously, central control of local governance in outlying towns was haphazard and hampered by systemic and structural difficulties ${ }^{59}$. By the seventeenth century, however, the Farnese dukes were demanding - and enforcing - involvement in the most minor conflicts in rural villages, regardless of feudal borders. Clearly, the Farnese dukes were not interested solely in social conflicts that featured physical violence. Rather, the judicial apparatus of the Farnese state encouraged officials to involve themselves actively in their villages' social fabric and quell tensions before or as they arose, referring all cases of potential violence to the central courts.

Secondly, the three malefactors noted in Orti's petition apparently had no intention of carrying their threat further at the time. Loading an archebus in front of his enemy was Pietro Rufaldi's particularly illustrative technique to demonstrate his superior male status. This was a very effective means to communicate hostility, because the cost, in terms of investment and involvement in a legal process, was relatively low compared to both the cost of physical violence and the benefit of

\footnotetext{
$56 \quad$ Ibid., bb40, \#1086.

57 Ibid., unnumbered petition of Nicolo Orti.

58 Burke (1998); Hanks (2010, Ch.1-3).

59 Connell, Zorzi (2000, pp. 165-183 \& 207-224).
} 
restraint. Of course, had Pietro fired the gun, either injuring or killing Lorenzo, he may not have escaped incarceration, exile or galley service. In addition, he would have lost the social capital associated with status and dominance in rural areas. Local towns too were thoroughly hierarchical, and villagers were well aware of the relationships and status of many of their covivants ${ }^{60}$. The simple solution was to load, but not fire, the weapon, thus counteracting both these costs of violence. As we have seen, the local official, Nicolo Orti, did not even bother to report this infraction to the central authorities, at least not in a timely manner. When he did report it and was punished for tardiness, his fine was promptly rescinded by the Dettatura. There are no further instructions to Orti for prosecuting the case. Thus, the legal cost of non-violent status display was effectively nil, compared to a steep judicial fine or the prospect of hard labour in the galleys and mines. By restraining personal violence in status displays and choosing non-violent aggression, Farnese subjects could avoid the judiciary entirely, or face a significantly reduced punishment for firearms infractions that the Dettatura, in all likelihood, would review favourably.

The years when soldiers were concentrated in the city and petitioned in unusually high numbers also provide the most reliable data on the success or failure of these petitions. For 1631, 1637 and 1687-1689, the bundles contain petitions that have the rescritto written directly on the document; in other years, common practice was to attach a small writ with a blot of wax, and these have not survived ${ }^{61}$. In 1631, of 83 total petitions included in the bundles, 62 received an affirmative rescritto while 21 did not, for a success rate of 74.6 percent. In 1637, the success rate is lower, at 61.1 percent (129/211), which could be related to the aftermath of Odoardo's 1636 campaign and the need to recuperate funds and restore order. Fifty years later, the picture is remarkably similar to that in 1631. In 1687-1689, of 456 petitions submitted, 346 were granted, for a success rate of 75.9 percent, practically indistinguishable from the 1631 rate. What these numbers tentatively indicate is the regularity with which ducal grace was dispensed, and the calculated use of mercy to promote the ducal persona without denigrating his authority and the judicial force that backed it.

The above petitions all concerned acts of violence committed by the petitioner, one of the two broad categories that concerned violence, and which attracted the personal attention of the duke. Broadly speaking, Farnese dukes, in particular Ranuccio II and his son Francesco (1694-1727), took an active interest in petitions that bore on their authority in relation to other regional princes and in those that potentially threatened the paternal relationship between themselves and their subjects. The latter category is most interesting, for it demonstrates how the Farnese regime provided for Parmans an alternative to violence. Subjects themselves responded to the opportunity for governmental intervention by referring conflicts with violent potential, or those with violent beginnings, to the duke and his ministers. This second category of petitions, concerning acts or threats of violence committed by the petitioner's rivals, also received the duke's personal attention.

Attached to letters between the duke, his councillors and his judges, the petitions of ordinary Farnese subjects expressed their fear of the violence, retaliatory or

\footnotetext{
60 Astarita (1999); Hanlon (2007); Smail (2003).

${ }^{61}$ ASPR, Supremo consiglio di giustizia e consiglio della dettatura, suppliche e memoriali, bb. 40, 43, 60.
} 
provocative, of their cohabitants in the city or outlying towns. In 1675 one of these vividly relayed the instability caused by the violence of roving men in the countryside. An unidentified cleric of Castellazzo begged the duke to provide his town with "some provisions that I think are necessary, so that in this and other states, no one will say that Your Highness does not commend himself highly to God, and to His honour" 2 . This petition followed a horrific raid carried out by "twelve or more armed men, to assassinate my household" and to "rob the women of their honour." In what seems at first an unrelated aside, the anonymous cleric emphasized the relationship upon which he based this request, a particularly interesting formulation from a churchman: the duke knew well the troubles of the church of Castellazzo (flooded, the cleric noted incidentally), where the petitioner "assisted for 35 and more years," and which was now about to collapse. The local bishop refused to fortify either the church or the town, and so the petitioner appealed to the duke for aid in protecting his household, because the duke did not have "[his] hand in anybody's purse." The petition requested town walls and guards to protect the church, such that Holy Mass could proceed without the fear of raid and rape on the town. Although the duke's response to this petition is not indicated, the present issues of authority, personality and protection make clear the function of petitioning in the context of violence: tools such as petitions enabled a population to turn to the ducal government for aid rather than pursue a private vendetta or live in perpetual fear. Conversely, the petitioners emphasized the grand authority of the duke, drawn directly from God and more useful, even to clergy, than the ecclesiastical hierarchy in securing the physical safety of Farnese subjects.

The most lucid evidence for this analysis emerges directly from the words of petitioners and dukes. Did they see themselves as shifting away from a system of private violence to one in which subjects' interests were best served by princely authority? Did Parman subjects no longer view their immediate kin networks as the first instance of safety, protection and legitimate quarrel and violence? A petition from one Barbara Galli, dated 1705, indicates her discomfort and fear at the prospect of her male relatives engaging in a kin $\mathrm{war}^{63}$. The feud began, in fact, between Barbara and her enemy, Giulia Zanelli, "a woman of much inferior condition to that of the petitioner," who "solely out of ill will fomented by her husband" harassed and "many times assaulted the honour of [Barbara], all of which also threatened her very life." Out of a desire to maintain "her proper decorum" Barbara "never wanted to cause the slightest injury[...] in all ways preventing this undertaking in which her husband and relatives will become involved," and had in fact moved her family to another part of the city, "principally to be remedied of any vendetta." This Parman subject demonstrates precisely the phenomenon under analysis here: by the eighteenth century, Parmans actively rejected private violence and employed the machinery of the state to prevent the outbreak of vendetta. Barbara appealed to the duke to "order your Uditore Criminale [...] to go to the house where Giulia presently lives, and command [her] to stay within the required limits" of her behaviour ${ }^{64}$.

62 ASPR, Atti Giudiziali, Lettere di Giustizia, bb32, 1675 Agosto-Dicembre, letter of 26 December.

63 ASPR, Uditore Criminale di Parma, Lettere Ducali ad'Uditore Criminale, bb33., unnumbered letter and attached petition of 29 September 1705.

64 The idea that this may refer to an early modern «restraining order» is tantalising but unverifiable. 
The dukes, too, made clear that they rejected the interpersonal violence of subjects, bringing their personal power to bear on even the domestic conflicts of subjects. Sexual and marital impropriety had for centuries been the jurisdiction primarily of local groups, usually comprising the town's or quarter's unmarried youthful males, who exercised an allegedly ritual violence against the bodies and properties of those they considered to have stepped beyond the bounds of local moral propriety ${ }^{65}$. But by the end of the seventeenth century, even this community enforcement of morality was frowned upon in Parma. Thus, in 1695, Francesco Farnese ordered his Uditore to,

observe this attached memorial, from a certain Barbara Preti, who says she is treated barbarously by her husband Basilio Grassi. This woman long served the Most Serene Princess Maria Maddalena [...] call this Basilio, and make him understand that if he does not change his ways, we will change them for him, along with other corrections from my hand ${ }^{66}$.

Barbara herself feared "to lose both her body and soul" at the hands of her husband, and evidently could not count on the moral indignation of the local youth to protect her from her husband's abuse. She relied on the only recourse she had: direct appeal to the duke, who fortunately bore her a particular good will based on her long connection to his own family.

This petition, and the Duke's reply, makes clear that Parmans participated willingly in the system of petition and appeal, effectively integrating their lives with the structures of local and ducal authority, such that even the marital household was subject to the intrusions and behavioural modifications of ducal justice. Further, the petitions served to create or to emphasize the personal connection between ruler and ruled for which the Farnese strove: both Barbara and Francesco referred to the former's personal service to the Farnese family, Barbara to influence the duke's decision, and Francesco to indicate the personal importance that he attached to Barbara's problems.

\section{CONCLUSION}

Alessandro Mariano's petition becomes clearer in this light. Mariano was aware of the high cost of justice. If he were blamed for this homicide, he faced steep fines, imprisonment or possible death. He therefore undertook to defend his innocence in this matter by offering to return to Parma and cooperate with the criminal judges. However, Mariano was clearly not totally innocent, or perhaps he had enemies within the judicial system. Therefore his participation in the judicial system was qualified: he would give himself up to the authorities, but he requested immunity from the law in all matters other than the homicide in question. This sense of negotiation captures very well the dynamic of petitioning: In order to function, the petitioning system had to offer real solutions to the problems of both government and population. Before

65 An instance of this is clear in Parma in a letter of 1675, in which the mattinata performed by a group of students was met by the archebus of the soldier they wished to shame. One of them ended up dead. ASPR, Atti Giudiziali, Lettere di Giustizia, Agosto-Dicembre 1675, bb32. Cf. Davis (1971); Thompson (1972). 
they would give up their use of violence, Parmans needed an effective alternative to protect their interests and safety.

Petitions provided an unrivalled opportunity for the Farnese princes to assume non-violent authority over the widely dispersed, traditionally feudal, villages and hamlets that comprised much of their territory. In Parma, this was surely aided by the relatively small size of the Duchy and its population, and the model presented here likely applies best to small-scale states such as those of northern Italy where such communication could function efficiently. The Farnese dukes did not hesitate to meddle in the business of their magistracies, and they consistently drew the power of the Dettatura closer to their individual purview. In constructing this magistracy, the Farnese dukes ensured that requests for mercy were directed immediately to the top of the hierarchy. This personal identification of mercy with ducal persona was both patriarchal, creating a metaphorical kin network in which subjects could appeal to their padrone to intervene in their disputes, and functional, allowing for a consistent presence of higher authority in the interactions between government and subject. At the same time, subjects' submission to this authority was not the product of that authority in and of itself; rather, subjects responded to the opportunity for ducal intervention in their quarrels, making any 'civilizing process' in Parma very much a cooperative affair between subjects and ruler.

The use of petitioning in such a light can also be brought to bear on the important historiographical issue of social control. Tomás Mantecón and Gerd Schwerhoff, dealing specifically with neighbourhood conflict and violence, make clear that communal behavioural standards, common ideas of violence, and an urge to negotiate settlements to conflict were part and parcel of interactions between individuals and with the forces of state authority in early modern Europe ${ }^{67}$. In their views, the interaction of institution and neighbourhood - 'from above' and 'from below' - is the driver of ideas and practices of social control. As Mantecón states, "popular spheres, social forces, and customary institutions never ceded their right to arbitrate disputes. Increasingly, they arbitrated everyday disputes by using local courts as the arena for discussion" 68 . Social discipline emerged from the goals and interactions of all members of society; petitions constitute a process by which those social goals are defined, elaborated and acted upon in legal settings.

The role of petitions across Europe as a tool used both by rulers, to inform themselves of and act upon the affairs of their subjects, and by those subjects, to find avenues for dispute resolution that precluded the necessities of violence and censured certain degrees of social behaviour, deserve further investigation in fullscale. This article has shown that in Farnese Parma, the control of violence cannot be seen as the result of one side or another's victory in the battle for social control. Rather, as the state attempted to expand its real control over the hearts and purses of subjects, individuals pursued those options which were, or seemed, most useful. Here the two perspectives on the decline of violence can come together. The evolution of legal systems provided the opportunity for the displacement of violence and personal conflict to abstract systems of threat and coercion. This is seen vividly in the preference of Parman soldiers for firearms display rather than gun violence; in both the interactions that predicated a judicial process and in the judicial process

\footnotetext{
67 Mantecón (2006, p. 268); Schwerhoff (2006, p. 236).

68 Mantecón (2006, p. 284).
} 
themselves, violence was diverted from physical action to theatrical posturing. People retained the mental structures that encouraged competition and aggression, but the institutional structure in which these emotions were played out promoted the channelling of this competition into non-violent arenas, such as displays of status, and the resolution of conflict in the tribunal system.

The system had its weaknesses, of course. Those with personal and professional connections to high levels of government obviously had better access to and success at the ducal court, as Barbara Preti's case vividly demonstrates. Additionally, it is important to recall that every successful petition that emerged from a court process dealing with a violent crime left a victim, or indeed, a double-victim: not only did the petitioner commit violence against his victim, the state then abetted this victimization by choosing rehabilitation over retribution. This could not satisfy everyone. Further, we must recall that petitions had a fiscal component as well. Each successful petition was taxed according to a rubric, and many petitioners found themselves in the position of having to appeal these costs as well. In terms of official corruption, cronyism and nepotism do not seem to be behind most ordinary petitions, but other archival deposits may prove otherwise. These petitions instead provide clear glimpses of the active choices made by Parmans of an alternative to personal violence in solving their social conflicts. As seen above, this rejection of violence was visible in the petitions of both men and women who did not have the resources, material or social, to pursue the feud and vendetta that characterises much of the violence noted by historians in medieval and early modern Europe ${ }^{69}$.

Colin Rose

Department of History

University of Toronto, Sidney Smith Hall 100 St George Street, Room 2074

Toronto, Ont. M5S 3G3, Canada Colin.rose@mail.utoronto.ca

\section{BIBLIOGRAPHY}

\section{Manuscript Sources}

Archivio di stato di Parma, Atti giudiziali, Lettere di giustizia, Bb 32.

Archivio di Stato di Parma, Computisteria di Parma e Piacenza, Suppliche e condanne, v 56. Archivio di Stato di Parma, Supremo Consiglio di Giustizia e di Grazia e Consiglio della Dettatura, Suppliche e memoriali, Bb 40, 43, 45, 5, 60, 65.

Archivio di Stato di Parma, Gride, V 40, 46, 47.Archivio di Stato di Parma, Uditore criminale, Lettere ducale ad'uditore criminale, Bb33.

Biblioteca Palatina, MS Parmeggiane, Miscellanea Farnesiana, \#554.

\section{Printed Sources}

Angelozzi, G., Nobiltà disciplinata: violenza nobiliare, procedure di giustizia e scienza cavalleresca a Bologna nel XVII secolo, Bologna, CLUEB, 2003.

$\overline{69} \quad$ Raggio (2001) ; Muir (1993, pp. 77-111). 
Anon., Lo sistema politico universale delli ducati di Parma e Piacenza, 1736-1737, in Di Noto, S. (ed.), Le istituzioni dei ducati Parmensi nella prima metà del settecento, Parma, Grafiche STEP Cooperativa, 1980.

Astarita, T., Village justice: community, family and popular culture in early modern Italy, Baltimore, Johns Hopkins University Press, 1999.

Beattie, J.M., 'The pattern of crime in England, 1660-1800', Past and present, 1974, 62, pp. 47-95.

Blaffer-Hardy, S., Hausfater, G. (Eds), Infanticide : comparative and evolutionary perspectives, New York, Aldine Pub. Co., 1984.

Burke, P., The European renaissance: centres and peripheries, Oxford, Blackwell, 1998.

Cancila, R. 'Per la retta amministrazione della giustitia': La giustizia dei baroni nella Sicilia moderna', Mediterranea: Ricerche storiche, 2009, 16, 6, pp. 315-352.

Carroll, S. Blood and violence in early modern France, Oxford, OUP, 2006.

Chambers, D.S., Dean, T., Clean hands and rough justice: an investigating magistrate in renaissance Italy, Ann Arbor, The University of Michigan Press, 1997.

Cockburn, J., Patterns of violence in English society: homicide in Kent, 1560-1985, Past and present, 1991, 130, pp. 70-106.

Collins, J. B., The State in Early Modern France (2 ${ }^{\text {nd }}$ edn.), Cambridge, CUP, 1995.

Connell, W.J., Zorzi, A. (Eds), Florentine Tuscany: structures and practices of power, Cambridge, CUP, 2000.

Daly, M., Wilson, M., Homicide, New York, Aldine de Gruyter, 1988.

Davis, N.Z., The reasons of misrule: youth groups and charivari in sixteenth-century France, Past and present, 1971, 50, pp. 41-75.

Davis, N.Z., Fiction in the archives: pardon tales and their tellers in sixteenth-century France, Stanford, Stanford University Press, 1987.

Di Noto, S. (ed.), Le istituzioni dei ducati Parmensi nella prima metà del settecento, Parma, Grafiche STEP Cooperativa, 1980.

Di Simplicio, O., Peccato penitenza perdono: Siena 1575-1800: la formazione della coscienza nell'Italia moderna, Milan, Franco Angeli, 1994.

Diamond, J., The third chimpanzee : the evolution and future of the human animal, New York, Harper Collins, 1992.

Dodd, G., Justice and grace : private petitioning and the English parliament in the late middle ages, Oxford, OUP, 2007.

Drei, G., Farnese : grandezza e decadenza di una dinastia italiana, Rome, Libreria Italiana, 1954.

Eisner, M., Long term historical trends in violent crime, Crime and Justice, 2003, 30, pp. 83142.

Eisner, M., Human evolution, history and violence: An introduction, The British journal of criminology, 2011, 51, pp. 473-478.

Elias, N., The civilizing process: sociogenetic and psychogenetic investigations, Malden, MA, Blackwell, 2000.

Forclaz, B., La famille Borghese et ses fiefs: L'autorité négociée dans l'état pontifical d'ancien régime, Rome, L'École française de Rome, 2006.

Fragnito, G. ed., Elisabetta Farnese: principessa di Parma e Regina di Spagna: atti del Convegno internazionale di studi, Parma, 2-4 Ottobre 2008, Roma, Viella, 2009.

Gallant, T., Honor, masculinity and ritual knife-fighting in nineteenth-century Greece, The American historical review, 2000, 105, pp. 359-382.

Gauvard, C., Les Clercs de la chancellerie royale française et l'écriture des lettres de rémission aux XIVe et XVe siècles, in Fianu, K., Guth, D. J. (dir.), Écrit et pouvoir dans les chancelleries médiévales : espace français, espace anglais, Louvain-la-Neuve, Fidem, 1997, 6, pp. 281-291. 
Given, J.B., Society and homicide in thirteenth-century England, Stanford, Stanford University Press, 1977.

Grossman, D., On killing: the psychological cost of learning to kill in war and society, Boston, Brown Little, 1995.

Hammer, C., Patterns of homicide in a medieval university town : fourteenth-century Oxford, Past and present, 1978, 78, pp. 3-23.

Hanks, W.F., Les rituels de l'agression en Aquitaine au XVII ${ }^{\mathrm{e}}$ siècle, Annales. Histoire, Sciences Sociales, 1985, 40, pp. 244-268.

Hanlon, G., Human nature in rural Tuscany: an early modern history, New York, Palgrave, 2007.

Henshall, N., The Myth of Absolutism : Change and Continuity in Early Modern European Monarchy, New York, Longman, 1992.

Hurnard, N., The king's pardon for homicide before AD 1307, Oxford, Clarendon Press, 1969.

Hyams, P., Rancor and reconciliation in medieval England, Ithaca, Cornell University Press, 2003.

Kesselring, K.J., Mercy and authority in the Tudor state, Cambridge, CUP, 2003.

Koziol, G., Begging pardon and favour: ritual and political order in early medieval France, Ithaca, Cornell University Press, 1992.

Logette, A., Le prince contre les juges: grâce ducale et justice criminelle en Lorraine au début du XVIII ${ }^{e}$ siècle, Nancy, Presses Universitaires de Nancy, 1994.

Mantecón, T., Social control from below: Popular arbitration of disputes in old regime Spain, in Spierenburg, P., Roodenburg, H. (Eds), Social control in Europe: 1500-1800, Columbus, OSU Press, 2006, pp. 267-287.

Meredith, B., The good death on the gallows: capital punishment in Parma, 1569-1731 (MA Thesis, Halifax, Dalhousie University), 2008.

Muchembled, R., La violence au village: sociabilité et comportements populaires en Artois $d u X V^{e}$ au XVII siècle, Turnhout, Editions Brépols, 1989.

Muchembled, R., Le temps des supplices: de l'obéissance sous les rois absolus, XVe-XVIII ${ }^{e}$ siècles, Paris, A. Colin, 1992.

Muir, E., Mad blood stirring: vendetta and factions in Friuli during the Renaissance, Baltimore, Johns Hopkins University Press, 1993.

Niccoli, O., Il seme della violenza: putti, fanciulli, e mammoli tra cinque e seicento, Rome, Laterza Editore, 1995.

Niccoli O., Perdonare: idee, pratiche, rituali in Italia tra cinquecento e seicento, Rome, Laterza Editore, 2007.

Nubola, C., Supplications between politics and justice: the northern and central Italian states in the early modern age, International review of social history, 2001, 46 (supplement), pp. 35-56.

Nubola, C., Belloni, C., Suppliche al pontefice: diocesi di Trento, 1513-1565, Bologna, Società editrice il Mulino, 2006.

Nubola, C., Wurgler, A. (Eds), Forme della communicazione politica in Europa nei secoli XVXVIII: suppliche, gravamine, lettere, Bologna, Società editrice il Mulino, 2004.

Parrott, D., Richelieu's army: war, government, and society in France, 1624-1642, Cambridge, CUP, 2001.

Pinker, S., The blank slate: the modern denial of human nature, New York, Viking Penguin, 2002.

Pinker, S. The better angels of our nature: why violence declined, New York, Penguin, 2011.

Rabbi Solari, G., The house of Farnese, New York, Doubleday and Company, 1968.

Raggio, O., Faide e parentele : lo stato genovese visto dalla Fontanabuona, Venice, Marsilio, 2001. 
Repetti, P., Scrivere ai potenti: suppliche e memoriali a Parma, secolo XVI-XVIII, Sogittura e civiltà, 2000, 24, pp. 295-358.

Rose, C., Grace from above: petitions and appeals in Farnese Parma, 1631-1727, MA Thesis, Halifax, Dalhousie University, 2010.

Schwerhoff, G., Social control of violence, violence as social control: The case of early modern Germany, in Spierenburg, P., Roodenburg, H. (Eds), Social control in Europe: 1500-1800, Columbus, OSU Press, 2006, pp. 220-246.

Sharpe, J.A., Crime in England: long-term trends and the problem of modernization, in Johnson, E.A., Monkkonen, E. (Eds), The civilization of crime: violence in town and country since the middle ages, Urbana, University of Illinois Press, 1996, pp. 17-34.

Shaw, J. Writing to the prince: Supplications, equity and absolutism in sixteenth-century Tuscany, Past and Present, 2012, 215, pp. 51-83.

Smail, D., The consumption of justice: emotions, publicity and legal culture in Marseille, 1264-1423, Ithaca, Cornell University Press, 2003.

Spierenburg, P., The spectacle of suffering : executions and the evolution of repression: from a preindustrial metropolis to the European experience, Cambridge, CUP, 1984.

Spierenburg, P., Faces of violence: homicide trends and cultural meanings: Amsterdam, 1431-1836, Journal of social history, 1994, 274, pp. 701-716.

Spierenburg, P., Long-term trends in homicide: theoretical reflections and Dutch evidence, fifteenth to twentieth centuries, in Johnson, E.A., Monkkonen, E. (Eds), The civilization of crime: violence in town and country since the middle ages, Urbana, University of Illinois Press, 1996, pp. 63-108.

Spierenburg, P. (ed.), Men and violence: gender, honor and ritual in modern Europe and America, Columbus, OSU Press, 1998.

Spierenburg, P., Violence and the civilizing process: does it work?, Crime, Histoire et Sociétés/Crime, History and Societies, 2001, 5, 2, pp. 87-105.

Spierenburg, P., A history of murder: personal violence in Europe from the middle ages to the present, Malden, MA, Polity Press, 2008.

Spierenburg, P., Roodenburg, H. (Eds), Social control in Europe: 1500-1800, Columbus, OSU Press, 2006.

Terpstra, N., Competing visions of the state and social welfare: the Medici dukes, the Bigallo magistrates, and local hospitals in sixteenth-century Tuscany, Renaissance quarterly, 2001, 54, 4, pp. 1319-1355.

Thompson, E.P., Rough music: le charivari anglais, Annales ESC, 1972, 27, 2, pp. 285-312.

Waquet, J.-C., Corruption: ethics and power in Florence, Pennsylvania, Pennsylvania State University Press, 1992. 